\title{
MEANING OF MONEY AMONG HINDUS IN INDIA: SOME PRELIMINARY FINDINGS.
}

\author{
Altaf Merchant, University of Washington, Tacoma, USA \\ Gregory M. Rose, University of Washington, Tacoma, USA \\ Mohit Gour, Issues \& Answers Network Inc, USA
}

\begin{abstract}
Understanding peoples' attitudes towards money is an important area of research, as the complex meanings attached to money motivate a variety of consumer behaviors (Rose and Orr, 2007). Exploring this phenomenon in an emerging market, like India, is timely and meaningful to both academics and practitioners. Culturally unique factors like the belief in 'Karma' and long term orientation has been known to influence consumer behaviors in India (Kopalle, Lehmann and Farley, 2010). However, there is no research which studies the effects of these cultural factors on attitude toward money. This becomes even more important as economic development heralds consumerism in emerging markets such as India. In this research, we study the meanings of money among Hindus through 24 qualitative interviews across three cities in India. Our findings add to the cross-cultural literature, and will be of interest to international marketers who are operating or evaluating doing business in emerging markets such as India, and targeting global consumers.
\end{abstract}

References available upon request. 